\title{
A Quasi Experimental Study to Evaluate the Efficacy of Problem Based Learning (PBL) Method on the Knowledge and Critical Thinking of Nursing Students about Normal Labour, in Selected Institution of Uttrakhand
}

\author{
Mehvish Khalid ${ }^{1}$, Dr Ratna Prakash ${ }^{2}$ \\ PHD Scholar, Shri Venkateshwara University Gajrola U.P, Vice Principal State School of Nursing Dehradun UK. \\ Principal Pal College of Nursing \& Medical Sciences, Haldwani UK
}

\begin{abstract}
Objectives of the study were to assess nursing students' knowledge and critical thinking about normal labour and develop a $P B L$ plan and evaluate the efficacy of PBL on the same. Quasi experimental (one group pre-test and post-test) research design was adopted with quantitative approach. Total enumeration sampling technique was used to obtain an adequate size of the sample. Forty nine (49) GNM third year nursing students were included in the study to achieve the appropriate power of the study. A structured knowledge questionnaire and critical thinking questionnaire were used for data collection. The overall mean pre and post-test knowledge score were found to be 10.0 \& 20.1 and standard deviation $1.61 \& 1.84$. And overall mean pre and post-test critical thinking score was found to be 7.6 \& 12.4 and standard deviation $1.65 \& 0.90$. Paired t test shows statistical significance at p<0.05 level. Conclusion- In this study the mean post-test knowledge and critical thinking scores were significantly higher than the mean pre-test knowledge and critical thinking scores of the nursing students. This indicated a significant difference between the effectiveness of problem based learning (PBL) method in developing nursing students' knowledge and critical thinking about normal labour.
\end{abstract}

Keywords: Efficacy, Problem Based Learning, Normal labour, Nursing students

\section{Introduction}

Problem-based learning (PBL) is a student-centered learning in which students learn about a subject through the experience of problem solving. Students learn both thinking strategies and domain knowledge. The goals of PBL are to help the students develop flexible knowledge, effective problem solving skills, self-directed learning, effective collaboration skills and intrinsic motivation. Problem-based learning is a style of active learning. ${ }^{1}$

Working in groups, students identify what they already know, what they need to know, and how and where to access new information that may lead to resolution of the problem. The role of the instructor (known as the facilitator in PBL) is to facilitate learning by supporting, guiding, and monitoring the learning process. ${ }^{2}$ The tutor must build students' confidence to take on the problem, and encourage the students, while also stretching their understanding. PBL represents a paradigm shift from traditional teaching and learning philosophy, ${ }^{3}$ which is more often lecture-based.

The constructs for teaching PBL are very different from traditional classroom/lecture teaching.

Barrows defines the Problem-Based Learning Model as: ${ }^{4}$

1) Student Centered Learning

2) Learning is done in Small Student Groups, ideally 6-10 people

3) Facilitators or Tutors guide the students rather than teach
4) A Problem forms the basis for the organized focus of the group, and stimulates learning

5) The problem is a vehicle for the development of problem solving skills. It stimulates the cognitive process.

6) New knowledge is obtained through Self-Directed Learning (SDL).

Introduction of PBL can bring major advancement in clinical care competency of nursing students by improving confidence, critical thinking, problem solving skills and lifelong learning skills. ${ }^{5}$

Problem Based learning had found encouraging students to think critically than students in traditional education. In a descriptive analytical study conducted by JC Martin, JW Dreck, among 52 fourth year students PBL model nursing school and 95 fourth year students at the schools where traditional educational model was implemented. California critical thinking disposition inventory was used to collect data and the critical thinking disposition were compared by using ' $t$ ' test. A statistically significant difference was found between the critical thinking disposition scores of the two groups. Analysis of subscale score showed that "open minded- ness" and "truth seeking" behaviour high in PBL group. ${ }^{6}$

The problem based learning and traditional educational methodology was compared among preclinical and clinical peritonitis by R.K. Santra Charles, F. Shuler. The preclinical and clinical knowledge test scores 234 undergraduate students from conventionally taught classes of 2003 and 


\section{International Journal of Science and Research (IJSR) \\ ISSN (Online): 2319-7064}

Index Copernicus Value (2016): 79.57 | Impact Factor (2015): 6.391

2004 were compares with scores of 274 dental from the PBL classes. Measurement for the study was the available scores from 2 preclinical examinations and one clinical competency examination conducted over their four academic year. The ' $t$ ' test analysis of the scores revealed that PBL students performed significantly better than the traditional students on midterm and final examination, but not for the clinical examination. Over a 2-year period, PBL students rated their program instruction at a mean of 4.41 on a 5-point Likert type scale. The study showed that the Problem Based Learning is a better strategy for teaching subjects. ${ }^{7}$

\section{Objectives of the study}

1)To assess the nursing students' knowledge and critical thinking about normal labour.

2)To evaluate the efficacy of PBL method on the nursing students' knowledge and critical thinking regarding normal labour.

\section{Hypothesis}

H1: On administration of PBL method there will be a significant difference between the mean pre-test and posttest knowledge and critical thinking scores of nursing students about normal labour.

\section{Methodology}

Quasi experimental one group pre-test post-test evaluative design was used in this study.

Total enumeration sampling technique was adopted for data collection. The sample was drawn from the selected nursing institution of Uttrakhand.

In this study independent variable was teaching method, it included PBL and dependent variables were nursing students' knowledge and critical thinking on normal labour.

Structured knowledge questionnaire and critical thinking questionnaire were used as research instruments for data collection. The Kudar Richardson (KR - 20) was used to calculate the reliability coefficient of knowledge questionnaire and critical thinking questionnaire. The value of ' $r$ ' was found to be $0.96 \& 0.91$ and indicating reliability of the tool. A written consent from the participants in the study was obtained. All the students were divided in four groups total 49 students were enrolled in GNM third year but 41 students were present during the data collection. Pretest knowledge questionnaire and critical thinking questionnaire were administered to nursing students then six PBL sessions were conducted according to PBL plan. Each small group was facilitated by the facilitator. Post-test was conducted after fifteen days.

\section{Teaching Aids}

PBL plan, books, Mannequins, lab articles, Instruments, Charts, posters, model and internet were used in this study.

\section{Results}

Characteristics of the sample subjects showed that maximum number of subjects $58.34 \%$ were in the age group of $19-23$ years, $94.44 \%$ were female, $76.04 \%$ were unmarried, and all the nursing students were $12^{\text {th }}$ passed.

Table 1: Mean, Standard deviation, Standard error and t value of pre and post- test of knowledge and critical thinking scores of nursing students about normal labour, $n=41$

\begin{tabular}{|l|l|l|l|l|l|}
\hline Variable & $\begin{array}{l}\text { Pre } \\
(\text { Mean } \pm \text { sd } \\
\end{array}$ & $\begin{array}{l}\text { Post } \\
(\text { Mean } \pm \text { sd } \\
)\end{array}$ & $\begin{array}{l}\text { Std. } \\
\text { Error } \\
\text { Mean }\end{array}$ & $\begin{array}{l}\mathrm{t} \\
\text { Value }\end{array}$ & P value \\
\hline Knowledg & $10.0 \pm 1.61$ & $20.1 \pm$ & .2448 & 41.29 & $\mathrm{P}<.000$ \\
$\mathrm{e}$ & & 1.84 & 8 & & 1 \\
\hline Critical & $7.6 \pm 1.65$ & $12.4 \pm$ & .2705 & 17.66 & $\mathrm{P}<.000$ \\
Thinking & & 0.90 & 4 & 0 & 1 \\
\hline \multicolumn{2}{|c|}{$\mathrm{df}=40$}
\end{tabular}

Paired t test was applied for the data analysis. The mean post-test knowledge and critical thinking scores were apparently higher than the pre-test knowledge and critical thinking scores and obtained t value was $40.29 \& 17.66$, which was significant at $\mathrm{p}<0.05$ level. Mean of pre-test knowledge and critical thinking score was computed as 10.0 \& 7.6 and also post-test knowledge and critical thinking score as $20.1 \& 12.4$. So the mean of post-test knowledge and critical thinking sores were higher than the mean pretest knowledge and critical thinking scores. The data is statistically significant.

Inference: Findings shows that Problem Based Learning (PBL) method was effective in improving the knowledge and critical thinking of nursing students about normal labour.

\section{Conclusion}

Normal labour is a physiological process by which the fetus, placenta and membranes are expelled through the birth canal, facilitated by the rhythmic contractions and relaxation of the uterus with consequent effacement and dilatation of the cervix. Normal labour includes Introduction, Physiology, stages, sign \& symptoms, Partograph, Mechanism and Management of mother during labour. This study has proved its efficacy, though on very limited number of subjects. Therefore it can be concluded that the PBL method is effective in developing the knowledge and improving the critical thinking of nursing students on normal labour.

\section{References}

[1] Hmelo-Silver, Cindy E. (2004). "Problem-Based Learning: What and How Do Students Learn?". Educational Psychology Review 16 (3): 235.

[2] Schmidt, Henk G; Rotgans, Jerome I; Yew, Elaine HJ (2011). "The process of problem-based learning: What works and why". Medical Education 45 (8): 792-806.

[3] Hung, Woei (2011). "Theory to reality: A few issues in implementing problem-based learning". Educational Technology Research and Development 59 (4): 529.

[4] Barrows, Howard S. (1996). "Problem-based learning in medicine and beyond: A brief overview". New Directions for Teaching and L earning 1996 (68): 3.

[5] Savery, J. R. (2006). Overview of Problem-based Learning: Definitions and Distinctions. Interdisciplinary Journal of Problem-based Learning, 1(1).

\section{Volume 6 Issue 12, December 2017}




\section{International Journal of Science and Research (IJSR) \\ ISSN (Online): 2319-7064}

Index Copernicus Value (2016): 79.57 | Impact Factor (2015): 6.391

[6] JC Martin, JW Dreck. In the introduction of a student centered, Problem Based Curriculum associated with improvement in student nurse well-being and performance? An Observational study of effect. Innovational journal of nursingstudies.2006; 43:941-952.

[7] RK Santra Charles, F Shuler. Problem-based learning versus a traditional educational methodology: A Comparison of pre clinical and clinical peridontics performance. Journal of Dental education, 2005;69(6):649-662.

\section{Author Profile}

Mehvish Khalid, PHD Scholar, Shri Venkateshwara University Gajrola U.P, Vice Principal State School of Nursing Dehradun UK.

Dr Ratna Prakash, Principal Pal College of Nursing \& Medical Sciences, Haldwani UK.

Volume 6 Issue 12, December 2017

www.ijsr.net 